\title{
Lexical Competence and Reading Comprehension: A Pilot Study with Heritage Language Learners of Spanish'
}

\section{Competencia Léxica y Comprensión de Lectura: Un Estudio Piloto con Estudiantes de Español como Lengua de Herencia}

\author{
Edna Velásquez ${ }^{2 *}$ \\ University of Houston, USA
}

\begin{abstract}
The basic questions that guide this study are: (a) what percentage of vocabulary from a passage would a Spanish learner need to know to demonstrate 'adequate' (a score of 70 out of 100) comprehension of it? And, (b) what type of curve would best describe the relationship between vocabulary knowledge and reading comprehension? Fifty-three students enrolled in two courses of Spanish as a Heritage Language (SHL) at a metropolitan university read a newspaper article, underlined the unknown vocabulary and then answered a reading comprehension test. Our findings suggest, as in previous studies for English as a Second Language (ESL), that a $98 \%$ of vocabulary coverage is needed to show adequate comprehension of an authentic passage. The curve that best describes this relationship was not linear as they concluded but was similar to a logarithmic function, which appears to suggest a relationship that obeys to a law of diminishing returns for Spanish as a Second Language (SSL) reading.

Keywords: Lexical competence, reading comprehension, Spanish as a Heritage Language
\end{abstract}




\section{Resumen}

Los dos interrogantes básicos que se abordan en este estudio son a) ¿Qué porcentaje de vocabulario de un pasaje debe conocer un estudiante de español para demostrar una comprensión 'adecuada' (un puntaje de 70 sobre 100)? y b) ¿Qué tipo de curva es la que mejor describe la relación entre vocabulario conocido y comprensión de lectura? Cincuenta y tres estudiantes matriculados en dos cursos de español como lengua de herencia en una universidad metropolitana leyeron un artículo periodístico, subrayaron el vocabulario desconocido y luego respondieron un cuestionario de comprensión de lectura. Nuestros resultados coinciden con los de algunos estudios previos para el inglés como segunda lengua, en donde se concluye que se necesita un $98 \%$ de cobertura de vocabulario para demostrar una comprensión adecuada de un pasaje auténtico. La curva que mejor describe esta relación resultó no ser lineal como en estudios previos, sino similar a una función logarítmica, lo que sugiere una relación que obedece a una ley de rendimientos decrecientes para la lectura en español como segunda lengua.

Palabras claves: Competencia léxica, comprensión de lectura, español como lengua de herencia

\section{Resumo}

Os dois interrogantes básicos que se abordam neste estudo são: a) Que porcentagem de vocabulário de uma passagem um estudante de espanhol deve conhecer para demonstrar uma compreensão 'adequada' (uma pontuação de 70 sobre 100)? e b) Que tipo de curva é a que melhor descreve a relação entre vocabulário conhecido e compreensão de leitura? Cinquenta e três estudantes matriculados em dois cursos de espanhol como língua de herança em uma universidade metropolitana leram um artigo jornalístico, sublinharam o vocabulário desconhecido e depois responderam um questionário de compreensão de leitura. Nossos resultados coincidem com os de alguns estudos prévios para o inglês como segunda língua, onde se conclui que se necessita um $98 \%$ de cobertura de vocabulário para demonstrar uma compreensão adequada de uma passagem autêntica. A curva que melhor descreve esta relação resultou não ser lineal como em estudos prévios, senão similar a uma função logarítmica, o que sugere uma relação que obedece a uma lei de rendimentos decrescentes para a leitura em espanhol como segunda língua.

Palavras chaves: Competência léxica, compreensão de leitura, espanhol como língua de herança 


\section{Introduction}

A fter several years of playing a secondary role in language teaching, vocabulary has recently gained prominence. This is in part due to the development of new language teaching approaches that grant it an important role in the process of second language acquisition and teaching. Applied linguists are now paying more attention to the study of vocabulary acquisition, the way learners store and retrieve words, and the pedagogical implications arising from these findings. Several research studies (Lafford, Collentine \& Karp, 2003; Mochida \& Harrington, 2006; and Read, 2000, among others) have found high correlations between vocabulary knowledge and other linguistic skills. While Kelly (1991) and Mecartty (2000) established a positive relationship between lexical competence and the development of listening skills, Hawas (1990), Koda (1989), Laufer (1992) and Meccartty (2000) found similar results for reading comprehension.

In particular, these studies about the relationship between lexical knowledge and reading comprehension have been done primarily for English as a first and second language. In addition, similar studies have been conducted for the case of English as a Foreign Language (EFL) in several countries. Some of these studies have been replicated for other languages, but there are still very few studies focusing on Spanish.

Scholars in the field of Heritage Languages (HL) have begun to explore the lexical competence of their speakers and its impact on the process of language (re)acquisition and teaching. For example, Polinsky and Kagan (2007) found high correlations between lexical proficiency and grammar knowledge for different heritage languages (Russian, Polish, Armenian, Korean, Lithuanian and Spanish). Fairclough (2013) designed a lexical recognition test containing words from A Frequency Dictionary of Spanish: Core Vocabulary for Learners (Davies, 2006). Her aim was to measure the vocabulary size of heritage language learners of Spanish in the USA. She concluded that receptive learners (those who understand Spanish but have limited oral skills or are unable to speak it) recognize around $60 \%$ (approximately 3000 items) of the 5000 most frequent words in Spanish, and that intermediate students recognize around $90 \%$ (about 4500 words from the 5000 most frequent). She then indicates that to be able to succeed in intermediate level classes designed for these learners, where an extensive reading of authentic material as well as writing is required, receptive learners would need to increase their lexical repertoire.

Since no empirical studies were found regarding the relationship between reading comprehension and lexical competence for heritage 
language learners (HLL) of Spanish, this work aims to contribute by beginning a discussion on this matter. Moreover, it will address the question of the existence of a lexical threshold, namely, the possible existence of an approximate percentage of words that students should know in order to understand an authentic reading passage.

\section{Literature Review}

Bravo (2011) notes that one of the first appearances of the concept of lexical competence can be found in Richards (1976). This researcher does not use the expression lexical competence but instead refers to knowing a word. The basic premises of his proposal are listed below:

1. Vocabulary knowledge of native speakers continues to expand in adult life, in contrast to the relative stability of their grammatical competence.

2. Knowing a word means knowing the degree of probability of encountering that word in speech or print. For many words, we also know the sort of words most likely to be found to be associated with the word.

3. Knowing a word implies knowing the limitations on the use of the word according to variations of function and situation.

4. Knowing a word means knowing the syntactic behavior associated with the word.

5. Knowing a word entails knowledge of the underlying form of a word and the derivations that can be made from it.

6. Knowing a word entails knowledge of the network of associations between that word and other words in the language.

7. Knowing a word means knowing the semantic value of the word.

8. Knowing a word means knowing many of the different meanings associated with a word. (Richards, 1976, p. 83)

As noted by López-Mezquita (2007), Richards' proposal is the starting point of a significant number of studies with different research approaches and has served as a framework for further studies on lexical competence. The most recognized and used taxonomy that compiles and further elaborates on Richard's components is Nation's (2001). For 
Nation, knowing a word means being able to account for components shown in Table 1 below.

Table 1. Nation's taxonomy of the components involved in knowing a word

\begin{tabular}{|c|c|c|}
\hline \multirow[t]{3}{*}{ Form } & spoken & $\begin{array}{l}\text { What does the word sound like? How is } \\
\text { the word pronounced? }\end{array}$ \\
\hline & written & $\begin{array}{l}\text { What does the word look like? How is } \\
\text { the word written and spelled? }\end{array}$ \\
\hline & word parts & $\begin{array}{l}\text { What parts are recognizable in this word? } \\
\text { What word parts are needed to express } \\
\text { the meaning? }\end{array}$ \\
\hline \multirow[t]{3}{*}{ Meaning } & form and meaning & $\begin{array}{l}\text { What meaning does this word form signal? } \\
\text { What word form can be used to express } \\
\text { the meaning? }\end{array}$ \\
\hline & $\begin{array}{l}\text { concept and } \\
\text { referents }\end{array}$ & $\begin{array}{l}\text { What is included in the concept? } \\
\text { What items can the concept refer to? }\end{array}$ \\
\hline & associations & $\begin{array}{l}\text { What other words does this make us think of? } \\
\text { What other words could we use instead of } \\
\text { this one? }\end{array}$ \\
\hline \multirow[t]{5}{*}{ Use } & $\begin{array}{l}\text { grammatical } \\
\text { functions }\end{array}$ & $\begin{array}{l}\text { In what patterns does the word occur? } \\
\text { In what patterns must we use this word? }\end{array}$ \\
\hline & collocations & $\begin{array}{l}\text { What words or types of words occur with } \\
\text { this one? }\end{array}$ \\
\hline & & $\begin{array}{l}\text { What words or types of words must we } \\
\text { use with this one? }\end{array}$ \\
\hline & constraints on use & $\begin{array}{l}\text { Where, when, and how often would we } \\
\text { expect to meet this word? }\end{array}$ \\
\hline & $\begin{array}{l}\text { (register, } \\
\text { frequency ...) }\end{array}$ & $\begin{array}{l}\text { Where, when, and how often can we use } \\
\text { this word? }\end{array}$ \\
\hline
\end{tabular}

(Nation, 2001, p. 27) 
The inclusion of the spoken form (pronunciation) and collocations stands out in this new model. In addition, Nation distinguishes between receptive and productive vocabulary, recognizing that productive skills require higher levels of knowledge than receptive skills.

Two other dimensions that have been traditionally studied as part of lexical competence are vocabulary size and depth. To refer to vocabulary size (the amount of known vocabulary) some authors use the term breadth, while for referring to the quality of vocabulary knowledge (the depth of knowledge of words), the term used is depth. Qian (1999) points out the lack of empirical studies that document the relationship between breadth and depth of vocabulary in reading comprehension. In a study with college students, he explored the role of breadth and depth of vocabulary in reading comprehension. He concludes that for ESL students knowing a minimum of 3000 word families, there is a high correlation between the scores in a reading comprehension test and those in two vocabulary tests (one testing breadth and the other testing depth).

Bravo (2011) confirms the results obtained by Qian for EFL students. The author measured the vocabulary size of thirty-three university students at a Chilean university by using the Vocabulary Levels Tests. She also determined the depth of knowledge of this same vocabulary by using the Word Associates Test. In addition, she assessed the students' level of reading comprehension using the reading comprehension section of the Test of English as a Foreign Language (TOEFL). This researcher concluded that the two dimensions breadth and depth of knowledge of vocabulary- are strongly related to reading comprehension. However, the author observed that the two factors do not predict reading comprehension with the same certainty. The strongest and most significant relationship that she found was between breadth and reading comprehension at the 3000 word level and academic vocabulary.

Both Bravo and Qian, among other linguists, also recognize that effective reading comprehension is not only the product of a high lexical competence (vocabulary size and depth). For them, reading is a complex process that requires many more skills besides lexical competence. In other words, for effective reading comprehension to take place, several factors play an important role. Among these factors, we can mention the following: a) grammar knowledge, b) previous cultural as well as topic knowledge, c) the effective use of reading strategies such as inference of meanings, d) personal skills to process information, e) personal motivation, and also f) the reader's ability to engage with the text, among others. However, while these factors are all very important 
in determining comprehension, it is the understanding of vocabulary that has shown to have the greatest impact, as discussed below.

As cited in Cartaya (2011), the relationship between reading comprehension and lexical competence had already been demonstrated for L1 reading by the eighties (Anderson \& Freebody 1981; Stanovich 1986; Sternberg 1987). For L2 Spanish, Mecartty (2000) examined the relationship between grammatical and lexical knowledge in reading and auditory tasks with college students. He found that both grammatical and lexical knowledge correlated significantly with reading, but only lexical knowledge accounted for both the variation in reading comprehension and listening comprehension.

Koda (2005) presents evidence to support the idea of a bidirectional nature of this relationship according to which vocabulary knowledge and reading comprehension are "functionally interdependent." The author states that both vocabulary comprehension and reading comprehension feed each other. That is to say, a reasonable amount of vocabulary contributes to being a good reader, and being a good reader is a key factor to acquiring more vocabulary. Readers learn vocabulary through reading and consequently increase their vocabulary by improving their reading skills.

Laufer (1997) concludes that the greatest obstacle that the reader faces to comprehend a text is the lack of vocabulary. She then suggests that the starting point for increasing comprehension would be to guarantee that students acquire a lexical competence that prevents interpretation errors and leads to successful inferences from the context. The reader should recognize enough sight words in order to gain a lexical competence that helps to overcome the obstacles that impede reading comprehension.

The question then arises: How much vocabulary does a second language reader need to know in order to evade the obstacles that arise in reading comprehension? In other words, what is the minimum amount of words L2 learners must have to be able to infer meaning and have a better understanding of a reading passage? Laufer (1989, 1992, and 1997), as well as Nation (1990, 2001 and, 2006), have agreed on postulating the existence of such a threshold in what is known as the Lexical Threshold Hypothesis. According to this hypothesis, there is a minimum amount of vocabulary that L2 learners need to possess in order to reach acceptable reading comprehension.

The first attempt to answer the question about the lexical threshold was Laufer (1989). The author investigated how much vocabulary L2 
English students from the University of Haifa needed to know to obtain a minimum score of $55 \%$ in a reading comprehension task. The score of $55 \%$ was the passing score required at the University of Haifa. This researcher asked the participants to underline the unknown words from a reading passage and then she adjusted the results with a translation test. From the experiment, she concluded that the amount of vocabulary necessary to understand a text was $95 \%$

After this initial attempt, there were and still are many others that seek to confirm this finding. Nevertheless, this still remains the most cited study and the frame of reference in the search for the lexical threshold in reading comprehension. However, the methodology used in this study was highly criticized, and even more controversial was the criterion of $55 \%$ used for proper reading comprehension.

Years later, Hu and Nation (2000) compared the effect of $80 \%$, $90 \%, 95 \%$ and $100 \%$ text coverage on reading comprehension of fictional texts among college ESL learners. They concluded that none of the participants reached comprehension at $80 \%$ coverage and only a few students at $90 \%$ coverage reached an acceptable comprehension. Some of the participants comprehended at $95 \%$ coverage, but most did not. According to these findings, the minimum lexical coverage that is necessary for an adequate comprehension of a fictional text is above $80 \%$. Furthermore, since coverage of $95 \%$ guarantees between $35 \%$ and $41 \%$ of comprehension for only some students, they conclude that a lexical coverage between $98 \%$ and $99 \%$ is necessary to achieve an adequate comprehension of a text.

More recently, Schmitt, Jiang, and Grabe (2011), in their study with ESL students at different universities around the world, seeks to determine the nature of the relationship between the percentage of known words in an academic text and comprehension of said text. A total of 661 intermediate ESL students from eight different countries were given a lexical recognition test with words from two reading passages, and they were later asked to answer a reading comprehension test about the passages. The results of this study confirm Hu and Nation's (2000) assertion that $98 \%$ of lexical coverage is needed to achieve a satisfactory comprehension of reading texts. The authors of this study also show that the nature of the relationship between the percentage of lexical coverage and the percentage of reading comprehension is linear. It means that the more words the student knows, the more comprehension is achieved at proportional increments.

To these empirical studies on the relationship between vocabulary and reading comprehension we can add the contribution of Davies (2005) 
for Spanish as a second language. The objective of his investigation was to determine the relationship between vocabulary range and text coverage for Spanish as a Second Language. The author concludes that with a limited vocabulary of 1000 frequent words, a learner of Spanish as a second language is capable of recognizing between $75 \%$ and $80 \%$ of all words in a written text in fiction, or non-fiction and around $88 \%$ of all the words in oral discourse. He also finds that after the 1000 word threshold, increasing vocabulary does not augment comprehension significantly. With double the amount of words (2000), the lexical coverage only increases between $5 \%$ and $8 \%$. Accordingly, with a vocabulary of 3000 words, lexical coverage increases only between $2 \%$ and $4 \%$. This is explained in Table 2. The author concludes that a "law of diminishing returns" is visible here - learning additional vocabulary after the first 1000 words does not necessarily imply a proportional increase in lexical coverage.

Table 2. Percent coverage by groups of words according to Davies (2005)

\begin{tabular}{|l|c|c|c|}
\hline & Fiction & Non fiction & Oral \\
\hline 1st thousand words & 76.0 & 79.6 & 87.8 \\
\hline 2nd thousand words & 8.0 & 6.5 & 4.9 \\
\hline 3rd thousand words & 4.2 & 3.5 & 2.3 \\
\hline FIRST 3000 words & 88.2 & 89.6 & 94.0 \\
\hline
\end{tabular}

It can be seen from Table 2 that, with a vocabulary of 3000 words, a student of Spanish as a Second Language would be able to understand between 80 and 90 percent of any written text and 94\% of a typical native speakers' conversation. These percentages are lower than the ones found for ESL by Laufer (1989) and $\mathrm{Hu}$ and Nation (2000).

Davies does not explicitly state it, nor is it the aim of his work, to describe the nature of the curve that best accounts for the relationship between known vocabulary and reading comprehension. However, from his findings, it can easily be inferred that if a law of diminishing returns is in effect, the type of curve that best describe this relationship would be a function of the type seen in Figure 1 and not a straight line like that of Figure 2, as Schmitt et al. (2011) concluded. 


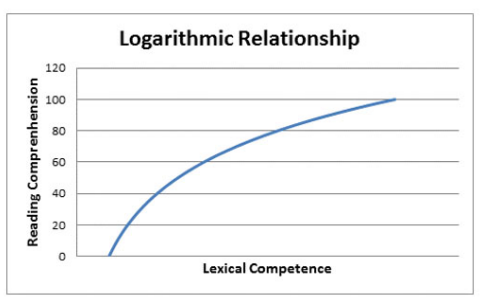

Figure 1. Relation between lexical competence and reading comprehension (Davies, 2005).

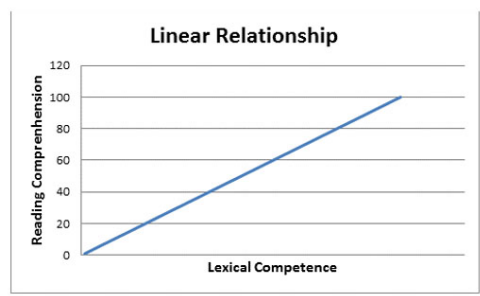

Figure 2. Relation between lexical competence and reading comprehension (Schmitt et al., 2011)

Indeed, for the latter, there is a proportional relationship between the amount of words known and reading comprehension, which means that comprehension increases proportionally with the amount of known vocabulary. Davies, on the other hand, asserts that knowing a larger number of words does not necessarily increase reading comprehension proportionally, given that the increments are progressively smaller with each gain in word knowledge. The best graph to illustrate this assertion is that of Figure 1.

The studies discussed so far are some of the most representative exploring the relationship between lexical competence and reading comprehension and some of the most cited studies for English and Spanish L2. Research on the same topic in Spanish as a heritage language (SHL) was found to be quite scarce, in part because this is a relatively recent field of study. As Kondo-Brown (2010) notes, there are no studies related to vocabulary and reading comprehension for SHL, except Rodrigo, McQuillan and Krashen (1996), a quasi-experimental study that examined the effect of free reading in the academic vocabulary learning of these students. The authors concluded that free reading is beneficial for heritage speakers as it contributes to the acquisition of vocabulary and improves the students' academic repertoire.

\section{Methodology}

\section{Research Design}

In order to acquire information on the relationship between lexical competence and comprehension of authentic texts for Heritage Language Learners of Spanish (HLLS), a pilot study was conducted with two intermediate groups at a major urban university in the Southwest of USA. The basic questions that guided this study were: (a) what percentage of words from an authentic passage would an 
HLLS need to know to demonstrate 'adequate' (a score of 70 out of 100) comprehension of it? And, (b) what type of curve (logarithmic --Davies, 2005-- or linear --Schmitt, Jiang \& Grabe 2011) would best describe the relationship between vocabulary knowledge and reading comprehension?

It is worth noting that $70 \%$ was chosen to be the cut point for 'adequate' comprehension to reflect what most USA higher education institutions consider to be a passing grade.

\section{Participants}

The participants in this study were 53 (34 female and 19 male) students enrolled in two intermediate level SHL courses at the abovementioned university. They were placed at this level after taking the institutional placement test for heritage Spanish learners.

\section{Data Collection Instruments}

The two instruments utilized for this study were a reading passage and a reading comprehension questionnaire designed and piloted by the author. The passage, El Clima Enloquecido, was an authentic newspaper article about climate change, containing 441 words. The questionnaire contained 10 multiple-choice comprehension questions, each with four choices.

The format chosen was that of a multiple-choice test which is widely used to test not only general knowledge but also reading comprehension. Schmitt et al (2011) refer to this format as "a standard in the field of reading research" (p. 32). Multiple choice tests have the advantage of being very practical to grade and they are very objective. Furthermore if, as suggested by Nation (2009), " 4 choices are given, the learners have only a 25 percent chance of guessing correctly." (p. 32)

All of the questions asked students to draw inferences from the text which according to Nation:

...involves taking messages from the text that are not explicitly stated but which could be justified by reference to the text. This can involve working out the main idea of the text, looking at the organization of the text, determining the writer's attitude to the topic, interpreting characters, and working out cause and effect and other conjunction relationships which might not be explicitly stated. (Nation, 2009, p. 34) 


\section{Procedure and Data Analysis}

After distributing the newspaper article, students were instructed to read it entirely, to identify the unknown words and underline them. Then, the reading comprehension questionnaire was handed out, and they were asked to read the article at least once more, and as many more times as needed, to answer the ten comprehension questions. Students had a total of 45 minutes to finish the test that was graded on a $0-100$ scale assigning 10 points for each right answer and 0 to every wrong answer.

Table 3 shows the reading comprehension scores with their corresponding frequencies and Figure 3 is the graph of their distribution.

Table 3. Reading comprehension scores and frequencies

\begin{tabular}{ccc} 
Score & frequency & \% \\
40 & 2 & $4 \%$ \\
50 & 2 & $4 \%$ \\
60 & 6 & $11 \%$ \\
70 & 12 & $23 \%$ \\
80 & 15 & $28 \%$ \\
90 & 11 & $21 \%$ \\
100 & 5 & $9 \%$ \\
\hline Average $=70$ & 53 & $100 \%$
\end{tabular}

Figure 3. Distribution of score frequencies for the reading comprehension test

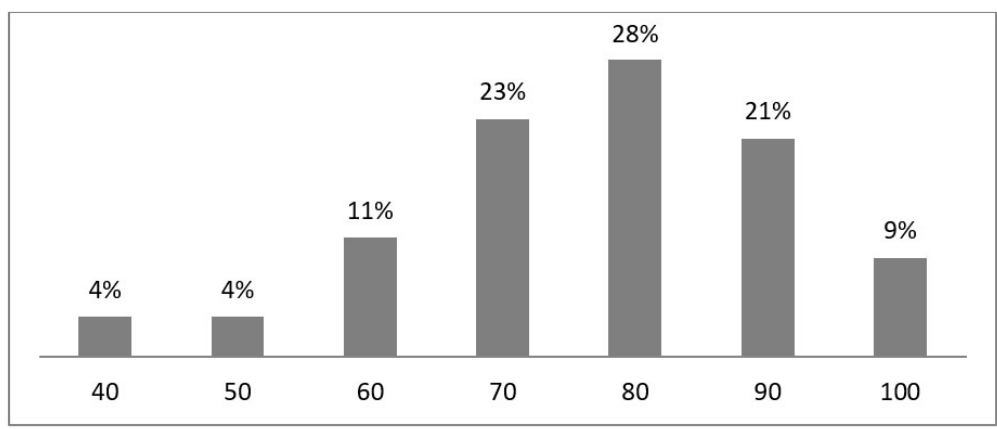

Subsequently, the underlined words in each one of the tests were counted to get the percentage of known words per student, and different ranges of lexical coverage were established for the whole sample. 
Finally, the average of the test scores on reading comprehension for each of the different ranges of lexical competence was found and all the data were tabulated.

\section{Results}

Figure 4 shows the average of the test scores on reading comprehension for each of the different ranges of lexical competence found. The graph demonstrates that a comprehension score of $70 \%$ is achieved somewhere between the 97.5 and 98.3 ranges of lexical competence, which seems to confirm Schmitt's findings for ESL. Our first question would then be answered by saying that this group of HLL demonstrates 'adequate' (a score of 70 out of 100) comprehension of an authentic reading passage when they recognize around $98 \%$ of the vocabulary from the reading passage.

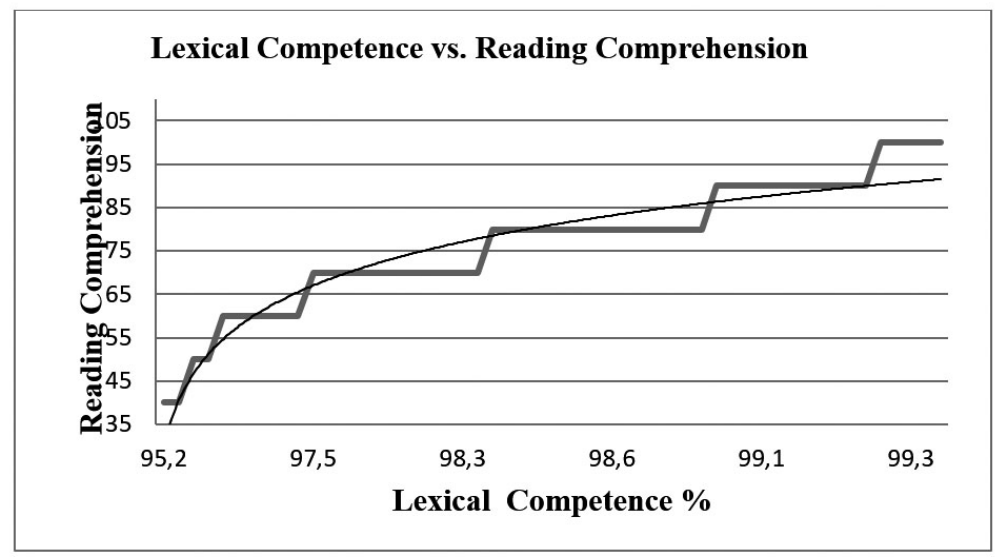

Figure 4. Average reading comprehension per range of lexical competence

Figure 4 reveals a nonlinear relationship, i.e. it does not reflect a proportional relationship between lexical competence and reading comprehension. Instead, it corresponds to a logarithmic function that would better reflect the law of diminishing returns suggested by Davies. In other words, in this particular experiment, greater lexical knowledge did not necessarily lead to a proportional increase in reading comprehension.

As mentioned before other factors besides lexical competence may affect reading comprehension. Factors such as the reader's grammatical 
knowledge as well as his or her familiarity with the discourse structure of the text must contribute in some way to the understanding of a written text. Also, textual factors, such as length, difficulty, or theme and individual factors, such as prior knowledge on the topic, interest, motivation, and ability to make inferences, must also influence a reader's ability to comprehend a text. Perhaps further studies of all of the above factors that affect reading comprehension would help us explain the type of graph found here.

\section{Conclusions}

It can be concluded then that at least for this group, the relationship between vocabulary knowledge and reading comprehension did not increase proportionally. The answer to our second question would be that the nature of the relationship between the percentage of known words and the score obtained in a test of reading comprehension of an academic text, obeys the law of diminishing returns, best represented by a logarithmic function, as suggested by Davies (2005).

One of the limitations of this study was the limited number of participants (only 53 students) and the fact that beginner and advanced students were not included in this study, only intermediate. For this reason, it is impossible to generalize these results to all SHL. Another limitation was the reliability of the lexical competence instrument, that is, the underlying procedure used to measure the students' lexical recognition that was criticized in Laufer's (1989) study with ESL students. Due to time restrictions, no additional tool was used to adjust the results obtained or to ensure that the students did not overestimate or underestimate their vocabulary knowledge. For future studies, it would be advisable to find a more reliable measure of lexical competence, such as a lexical recognition test and to use additional measures of reading comprehension such as reading recall protocol instruments, translation tasks, summaries, cloze tests, etc. Future empirical studies could also address the same research questions but with different types of texts such as fiction and non-fiction.

As of July 1, 2012, 53 million was the estimated Hispanic population of the United States (17\% of the total) and it is projected that by the year 2060 , it will reach 128.8 million residents $(31 \%$ of the total). Not surprisingly, Spanish is the second most-spoken language in USA with over 800,000 students (more than half of the total FL enrollment) taking Spanish classes in institutions of higher education (MLA survey, Fall 2006). The high demand for Spanish classes not only for second language learners but also for heritage language learners is 
evident. In spite of this, research in the area is still scarce and language professionals continue to base their pedagogical practice, curriculum design as well as instructional and testing materials on research findings for ESL. Given the growing demand for Spanish as a foreign and as a heritage language, it is imperative that scholars in the field start conducting their own research to identify effective teaching practices and curricular design.

The importance of this study is that it helps corroborate the findings of previous research in ESL for SHL. According to these studies, vocabulary knowledge plays a much more important role in reading comprehension than it was previously recognized. If as shown here a large vocabulary is indeed the key to understanding and dissecting a text, it is clear that students need to devote more time and energy to the acquisition of certain high-frequency words. Instructional as well as testing material and curriculum design should also reflect this reality in order to achieve better results in the process of (re)acquisition of Spanish.

As for lexical competence, it should be promoted from the basic levels and it should be reinforced throughout all courses. The implementation of all the traditional techniques of learning vocabulary, such as using high-frequency words lists, vocabulary flashcards, semantic maps, or word families as well as instruction on the use of the dictionary, are highly recommended. Extensive reading activities are also very effective, especially at intermediate and advanced levels, to promote the development of a greater lexical repertoire. Although it has been widely recognized the important role that extensive reading plays in vocabulary acquisition and in the development of strategies and reading skills, this activity is often neglected by students and instructors. For this reason, it is recommended that instructors provide sufficient opportunities for reading in Spanish, both inside and outside the classroom.

The nature of the relationship between lexical competence and reading comprehension found here makes evident that although vocabulary is an important factor in reading comprehension, it is not the only one. In fact, a large number of variables (such as grammatical knowledge, background knowledge, awareness of discourse structure, etc.) make independent contributions to reading comprehension. A thorough examination of all the variables that influence reading comprehension is impossible to accomplish in a single study. Therefore, it is recommended to continue conducting both qualitative and quantitative research to advance, confirm and validate previous results 
for ESL. Hopefully, in the future, these findings will be reflected in effective teaching practices and curriculum design as well as appropriate instructional materials for SHL.

Researchers, instructors, students and all those committed to the development and maintenance of heritage languages and advanced biliteracy for their speakers, need a deeper understanding of the complexity of the reading process. SHL students, in particular, pose new challenges to instructors. With this population, the principal language instruction objective pursued is to maximize the use of resources that these students already possess. However, once heritage learners have achieved this lexical access threshold, it is important not to disregard the other factors that might affect reading comprehension as well. 


\section{References}

Anderson, R., \& Freebody, P. (1981). Vocabulary knowledge. In J.T. Guthrie (Ed.), Comprehension and Teaching: Research Reviews. Newark, DE: International Reading Association.

Bravo, R. (2011). Relaciones entre cantidad y calidad del conocimiento léxico y la comprensión de lectura en aprendientes de inglés como lengua extranjera. Lenguas Modernas, 37, 11-31.

Cartaya, F. (2011). La hipótesis del umbral léxico en la comprensión de lectura en L2. Revistas cientificas y humanisticas Luz. Retrieved from: $\quad$ http://produccioncientificaluz.org/index.php/lingua/article/ view/17263/17236

Davies, M. (2005). Vocabulary Range and Text Coverage: Insights from the Forthcoming Routledge Frequency Dictionary of Spanish. In D. Eddington (Ed.), Selected Proceedings of the 7th Hispanic Linguistics Symposium (pp. 106-115). Somerville, MA: Cascadilla Proceedings.

Davies, M. (2006). A frequency dictionary of Spanish: Core vocabulary for learners. New York: Routledge.

Fairclough, M. (2013). El "(re)conocimiento" del léxico español del estudiante hispano bilingüe en los Estados Unidos. In Dumitrescu, D. \& Piña-Rosales, G (Eds.), El Español en los Estados Unidos: E pluribus unum? Enfoques multidisciplinarios. New York: Academia Norteamericana de la Lengua Española.

Hawas, H. M. (1990). Vocabulary and Reading Comprehension: An Experimental Study. International Review of Applied Linguistics, 87-88, 43-65.

Hu, M., \& Nation, I. P. (2000). Vocabulary density and reading comprehension. Reading in a Foreign Language, 13(1), 403-430.

Kelly, P. (1991). Lexical Ignorance: The Main Obstacle to Listening Comprehension with Advanced Foreign Language Learners. International Review of Applied Linguistics in Language Teaching, 29(2), 135-149. doi:10.1515/iral.1991.29.2.135

Koda, K. (1989). The effects of transferred vocabulary knowledge on the development of L2 reading proficiency. Foreign Language Annals, 22, 529-540.

Koda, K. (2005). Insights into second language reading: A crosslinguistic approach. Cambridge, UK: Cambridge University Press. 
Kondo-Brown, K. (2010). Curriculum Development for Advancing Heritage Language Competence: Recent Research, Current Practices, and a Future Agenda. Annual Review of Applied Linguistics, 30, $24-$ 41. doi:10.1017/S0267190510000012

Lafford, B. A., Collentine, J. G., \& Karp, A. S. (2003). The Acquisition of Lexical Meaning by Second Language Learners: An Analysis of General Research Trends with Evidence from Spanish. In B. Lafford, R. Salaberry (Eds.), Spanish second language acquisition: State of the science (pp. 130-159). Washington, DC: Georgetown UP.

Laufer, B. (1989). What Percentage of Text-Lexis Is Essential for Comprehension? In C. Laurén, M. Nordman (Eds.), Special language: From humans thinking to thinking machines (pp. 316323). Clevedon: Multiling. Matters.

Laufer, B. (1991). How Much Lexis Is Necessary for Reading Comprehension? In Arnaud, P. \& Béjoint, H. (Eds.), Vocabulary and Applied Linguistics (pp. 126-132). Macmillan Academic and Professional.

Laufer, B. (1992). Reading in a foreign language: how does L2 lexical knowledge interact with the reader's general academic ability? Journal of Research in Reading 15(2): 95-103.

Laufer, B. (1996). The lexical threshold of L2 reading: where it is and how it relates to $\mathrm{L} 1$ reading ability. In K Sajavaara and C. Fairweather, (Eds.), Approaches to second language acquisition (pp. 55-62). Jyvaskyla: Cross Language Studies.

Laufer, B. (1997). The lexical plight in second language reading: words you don't know, words you think you know, and words you can't guess. In J. Coady, T. Huckin (Eds.), Second language vocabulary (pp. 20-34). Cambridge: Cambridge UP.

López-Mezquita, M. (2007). La evaluación de la competencia léxica: tests de vocabulario, su fiabilidad y validez (Doctoral Dissertation). Granada, España: Editorial Universidad de Granada.

Mecartty, F. H. (2000). Lexical and grammatical knowledge in reading and listening comprehension by foreign language learners of Spanish. Applied Language Learning, 11(2), 323-348.

Mochida, A., \& Harrington, M. (2006). The Yes/No test as a measure of receptive vocabulary knowledge. Language Testing, 23(1), 73-98. doi:10.1191/02655322061t321oa

Nation, I. P. (1990). Teaching and learning vocabulary. New York: Newbury House. 
Nation, I. P. (2001). Learning vocabulary in another language. Cambridge, England: Cambridge UP.

Nation, I. P. (2006). How large a vocabulary is needed for reading and listening? Canadian Modern Language Review/La Revue Canadienne Des Langues Vivantes, 63(1), 59-82. doi:10.1353/ cml.2006.0049

Nation, I. P. (2009). Teaching ESL/EFL reading and writing. New York: Routledge.

Polinsky, M, \& Kagan, O. (2007). Heritage languages: In the 'wild' and in the classroom. Language and Linguistics Compass, 1(5), 368-395.

Qian, D. (1999). Assessing the roles of depth and breadth of vocabulary knowledge in reading comprehension. Canadian Modern Language Review, 56(2), 282-308.

Read, J. A. S. (2000). Assessing vocabulary. Cambridge: Cambridge University Press.

Richards, J. C. (1976). The role of vocabulary teaching. TESOL Quarterly, 10, 77-89.

Rodrigo, V., McQuillan, J., \& Krashen, S. (1996). Free Voluntary Reading and Vocabulary Knowledge in Native Speakers of Spanish. Perceptual and Motor Skills, 83(2), 648-650.

Schmitt, N., Jiang, X., \& Grabe, W. (2011). The Percentage of Words Known in Text and Reading Comprehension. Modern Language Journal, 95(1), 26-43. doi:10.1111/j.1540 4781.2011.01146.x

\section{Author}

*Edna Velásquez teaches Spanish as a Heritage and as a Second Language at the University of Houston. She holds a MA, and $\mathrm{PhD}$ in Spanish Linguistics from the same Institution. Her areas of interest and research are Spanish as a Heritage Language; Bilingual and Heritage Language Education; Spanish/English as a Second Language; Sociolinguistics and U.S.A Spanish. 